\title{
DIDACTICAL DESIGN RESEARCH (DDR) PADA HUKUM PASCAL BERDASARKAN KESULITAN BELAJAR SISWA KELAS X MAN CILILIN KABUPATEN BANDUNG BARAT
}

\author{
Adam Hadiana Aminudin1, Yudi Dirgantara1, dan Heni Rusnayati' \\ 1. Program Studi Pendidikan Fisika, Jurusan Pendidikan Matematika dan Ilmu \\ Pengetahuan Alam,Fakultas Tarbiyah dan Keguruan Universitas Islam Negeri Sunan \\ Gunung Djati Bandung, Indonesia \\ 2. Program Studi Pendidikan Fisika, Jurusan Pendidikan Fisika, Fakultas Matematika \\ dan Ilmu Pengetahuan Alam Universitas Pendidikan Indonesia, Bandung Indonesia
}

\section{Email: yudidirgantara@uinsgd.ac.id}

\begin{abstract}
ABSTRAK
Penelitian Didactical Design Research (DDR) merupakan penelitian kualitatif dengan metode deskriptif. Tujuannya untuk membuat desain pembelajaran dalam rangka meminimalisasi kesulitan belajar siswa pada Hukum Pascal. Populasi pada penelitian ini yaitu siswa kelas X MAN Cililin, sedangkan teknik pengambilan sampel yang dilakukan yaitu teknik purposive sampling. Langkah pertama untuk mengetahui kesulitan belajar siswa pada Hukum Pascal yaitu dengan mengetahui Learning Obstacle yang pada penelitian kali ini hanya difokuskan pada epistemology obstacle, maka siswa kelas XI MAN Cililin yang sudah mempelajari Hukum Pascal diberi soal esay sebanyak lima nomor. Dari jawaban siswa tersebut didapat data kesulitan belajar siswa pada Hukum Pascal. Dari data kesulitan tersebut, kemudian dibuatlah desain pembelajaran yang disesuaikan dengan kesulitan belajar siswa pada Hukum Pascal. Desain yang diimplementasikan selalu mengalami perbaikan di setiap pertemuannya. Hal ini dilakukan agar desain yang dibuat bisa lebih baik lagi, sehingga kesulitan belajar siswa pada Hukum Pascal dapat diminimalisasi. Berdasarkan hasil penelitian, dapat disimpulkan bahwa kesulitan belajar siswa pada Hukum Pascal dapat diminimalisasi.
\end{abstract}

Kata kunci: Didactical Design Research (DDR), kesulitan belajar siswa, Hukum Pascal

\begin{abstract}
Didactical Design Research (DDR) is a qualitative research with descriptive methods. Aim to make learning design in order to minimize the difficulties of students in Pascal's Law. The population in this research is class X MAN Cililin, while a sampling technique is purposive sampling. The first step for know the student's learning difficulties in Pascal's Law with knowing Learning Obstacle which this research only focused on epistemology obstacle, so the students of class XI MAN Cililin who had studied Pascal's Law given five numbers essay. From the student's answers obtained data the student's learning difficulties in Pascal's Law. From the difficulty of the data, created learning design be adapted with the student's learning difficulties in Pascal's Law. The design is implemented always improved in every meeting. This is done, and the design can be made better, so that student's learning difficulties in Pascal's Law can be minimized.
\end{abstract}

Keywords: Didactical Design Research (DDR), student's learning difficulties, Pascal's Law 


\section{PENDAHULUAN}

Fisika merupakan bagian dari Ilmu Pengetahuan Alam (IPA) yang harus dipelajari di tingkat SMA/MA/sederajat. Pentingnya mata pelajaran fisika karena fisika termasuk dalam salah satu mata pelajaran yang terdapat pada Ujian Nasional. Selain itu pada pembahasannya fisika juga mempelajari tentang berbagai fenomena alam yang sering terjadi dalam kehidupan sehari-hari. Mempelajari fisika tidaklah sulit jika selalu dikaitkan dengan pengalaman yang ada pada siswa tentang fenomena alam. Kaitan yang bisa diambil dari pelajaran fisika salah satunya dari penemuan siswa tentang fenomena alam yang terjadi di sekitarnya. Sains pada dasarnya merupakan ilmu pengetahuan yang mencari tahu tentang alam secara sistematis dari suatu proses penemuan (Sunarto, 2011).

Peran guru sangatlah penting pada saat proses pembelajaran fisika, bagaimana cara menyampaikan materi, serta motivasi belajar yang diberikan kepada siswa, sehingga mata pelajaran fisika bisa mudah dipahami. Guru dalam proses pembelajaran di kelas dipandang dapat memainkan peran penting terutama dalam membantu peserta didik untuk membangun sikap positif dalam belajar, membangkitkan rasa ingin tahu, mendorong kemandirian dan ketepatan logika intelektual, serta menciptakan kondisikondisi untuk sukses dalam belajar (Ismail, 2010).

Namun sebagian siswa justru menganggap mata pelajaran fisika sulit untuk dipelajari. Baik dari segi konsep, maupun dari rumus yang terdapat dalam fisika. "Kesulitan belajar tidak selalu disebabkan karena faktor intelegensi yang rendah, tetapi juga oleh faktor psikologi lain. Penyelidikan-penyelidikan yang dapat dilakukan untuk mengetahui kesulitan belajar siswa, adalah dengan mengadakan observasi, interview, tes diagnostik, dan memanfaatkan dokumentasi" (Rusilowati, 2006). Sehingga peneliti mengambil sub materi fluida statis yaitu Hukum Pascal yang akan dilihat kesulitan belajar siswa pada materi tersebut.
Berdasarkan hasil wawancara dengan siswa yang telah mendapatkan materi fluida yaitu kelas XI IPA MAN Cililin dan guru mata pelajaran fisika, ternyata materi fluida termasuk ke dalam materi yang sulit untuk dipahami, yang salah satu sub bab nya adalah Hukum Pascal. Kesulitan yang dialami siswa diantaranya, jika materi yang diterangkan sekali oleh guru, siswa merasa belum paham, namun setelah dimasukan pada contoh soal baru siswa merasa paham. Ketika soalnya diubah sedikit saja siswa merasa kebingungan kembali. Kemudian siswa juga kebingungan untuk menentukan rumus yang harus digunakan dalam mengerjakan suatu soal, namun jika sudah dikasih tau awalnya saja, siswa langsung paham maksud dari soal yang diberikan. Sehingga peneliti menganggap bahwa kesulitan siswa dapat dikategorikan sebagai hambatan epistimologis atau epistimological obstacle.

Setelah melihat permasalahan di atas, ternyata terdapat kesulitan belajar pada Hukum Pascal, sehingga peneliti tertarik untuk meneliti labih dalam mengenai kesulitan belajar siswa dan mencoba meminimalisasi kesulitan belajar tersebut dengan menggunakan deisain yang bernama Didactical Design Research (DDR). Penelitian dalam pembuatan Didactical Design Research (DDR) telah dilakukan oleh beberapa peneliti, seperti Didi Suryadi dalam penelitiannya "Didactical Design Research (DDR) Dalam Pengembangan Pembelajaran Matematika", penelitian Nur Fadhillah dalam "Desain Didaktis Konsep Vektor Pada Pembelajaran Fisika SMA Kelas X", serta penelitian Mar'ia Rita Otero, Marcelo Arlego, Fabiana Prodanoff, dalam "Design, Analysis And Reformulation of A Didactic Sequence For Teaching The Special Theory of Relativity In High School". Dari penelitian yang sudah dilakukan, pembuatan desain didaktis bisa digunakan untuk meminimalisasi kesulitan belajar. Sehingga peneliti akan mencoba menggunakan Didactical Design Research (DDR) untuk meminimalisasi kesulitan belajar siswa pada Hukum Pascal. Dengan suatu desain didaktis yang berorientasi pada hambatan-hambatan yang dialami oleh siswa, diharapkan siswa tidak lagi menemui hambatan-hambatan yang berarti pada 
saat proses pemahaman konsepnya (Nur'ela dkk, 2013).

Berdasarkan pemaparan di atas, maka akan dilakukan penelitian dengan judul "Didactical Design Research (DDR) Pada Hukum Pascal Berdasarkan Kesulitan Belajar Siswa Kelas X MAN Cililin Kabupaten Bandung Barat". Permasalahn yang diambil pada penelitian ini meliputi: (1) Bagaimana kesulitan belajar siswa kelas X MAN Cililin pada Hukum Pascal?; (2) Bagaimana bentuk desain didaktis untuk meminimalisasi kesulitan belajar siswa kelas X MAN Cililin pada Hukum Pascal?; (3) Bagaimana keterlaksanaan kegiatan pembelajaran desain didaktis berdasarkarkan lembar observasi pada Hukum Pascal?

\section{METODE PENELITIAN}

Penggunaan metode pada pelitian ini menggunakan metode deskriptif, dengan tujuan desain yang dibuat merupakan rancangan hasil analisis wawancara dan soal Tes Kemampuan Responden (TKR) awal yang diberikan kepada siswa yang sudah mempelajari Hukum Pascal. Sehingga jenis data yang akan digunakan dalam penelitian ini adalah data kualitatif. Penelitian kualitatif (Qualitative research) adalah suatu penelitian yang ditujukan untuk mendeskripsikan dan menganalisis fenomena, peristiwa, aktivitas social, sikap, kepercayaan, persepsi, pemikiran orang secara individual maupun kelompok (Sukmadinata, 2012).

Adapun data yang dianalisis berupa data hasil lembar observasi keterlaksanaan kegiatan guru dan siswa yang telah diisi oleh observer dan data hasil jawaban siswa dalam mengisi soal TKR.

Untuk analisis data lembar observasi digunakan sebagai pendukung dalam analisis metapedadidaktik yang merupakan implementasi dari desain didaktis yang telah dibuat, menggunakan rumus:

$$
S=\frac{R}{N} \times 100 \%
$$

Dimana S: nilai yang diharapkan (dicari), R: jumlah skor yang didapat, dan $\mathrm{N}$ : skor maksimum (Purwanto, 2008).

Sedangkan untuk analisis soal TKR digunakan untuk melihat keberhasilan desain yang dibuat dalam meminimalisasi kesulitan belajar siswa dalam mempelajari Hukum Pascal. Peneliti mulanya akan mengelompokan kesulitan belajar siswa yang didapat dari jawaban TKR awal yang diberikan kepada siswa kelas XI IPA yang sudah menerima materi Hukum Pascal. Kemudian peneliti akan menyajikan setiap data kesulitan belajar siswa tersebut dalam bentuk persentase dengan cara sebagai berikut:

kesulitan $=\frac{\text { banyaknya siswa yang mengalami kesulitan }}{\text { jumlah seluruh siswa }} \times 100 \%$

Populasi dalam penelitian ini adalah siswa kelas $\mathrm{X}$, karena peneliti ingin mengetahui kesulitan belajar siswa kelas X MAN Cililin pada Hukum Pascal. Dalam pengambilan sampel, peneliti menggunakan teknik purposive sampling, mengingat peneliti hanya meneliti kelas yang semua siswanya mempelajari fisika, maka sampel yang digunakan adalah kelas X MIA.

\section{Kesulitan Belajar}

Kesulitan belajar merupakan keadaan yang menunjukkan bahwa siswa tidak mampu belajar sebagaimana mestinya (Rusilowati, 2007). Untuk mengetahui penyebab siswa merasa kesulitan dalam mempelajari Hukum Pascal, langkah pertama yang harus dilakukan adalah dengan mengetahui learning obstacle yang pada penelitian kali ini hanya difokuskan pada epistemology obstacle. Epistemological obstacles, in contrast, are those that arise regardless of the instructional approach, for their origin is the concept itself; in other words, "to overcome the obstacle is part of the construction of the meaning" of the concept (Stacy, 2008). Sedangkan menurut Duroux (Suryadi, 2013) mengatakan bahwa, epistimological obstacle pada hakekatnya merupakan pengetahuan seseorang yang hanya terbatas pada konteks tertentu. Sehingga jika orang tersebut dihadapkan pada konteks 
berbeda, maka pengetahuan yang dimiliki menjadi tidak bisa digunakan atau dia mengalami kesulitan untuk menggunakannya.

\section{Didactical Design Research (DDR)}

Didactical Design Research (DDR) merupakan penelitian tentang pembuatan desain pembelajaran berdasarkan kesulitan belajar siswa. Penelitian DDR ini pada dasarnya terdiri atas tiga tahapan yaitu analisis situasi didaktis sebelum pembelajaran, analisis metapedadidaktik, dan analisis retrosfektif. Dari ketiga tahapan ini akan diperoleh Disain Didaktis yang tidak tertutup kemungkinan untuk terus disempurnakan melalui tiga tahapan DDR tersebut (Suryadi, 2013).

Tahap awal dari penelitian DDR adalah analisis situasi didaktis sebelum pembelajaran yang wujudnya berupa Desain Didaktis Hipotesis termasuk Antisipasi Didaktis dan Pedagogis (ADP). Pada tahap ini guru menganalisis kesulitan belajar siswa dari jawaban soal TKR awal, yang kemudian akan dibuat disain didaktis hipotesis beserta prediksi respon siswa melalui ADP yang diberikan.

Terdapat dua aspek mendasar dalam proses pembelajaran, yaitu hubungan siswamateri dan hubungan guru-siswa, dimana dari kedua aspek tersebut dapat menciptakan situasi didaktis. Hubungan antara guru, siswa, dan materi digambarkan oleh Kansanen sebagai sebuah Segitiga Didaktis yang menggambarkan Hubungan Didaktis (HD) antara siswa dan materi, dan Hubungan Pedagogis (HP) antara guru dan siswa. Ilustrasi kansanen belum menggambarkan hubungan guru-materi sehingga akan memunculkan situasi yang baru yang tidak diantaisipasi sebelumnya oleh guru (Suryadi, 2013).

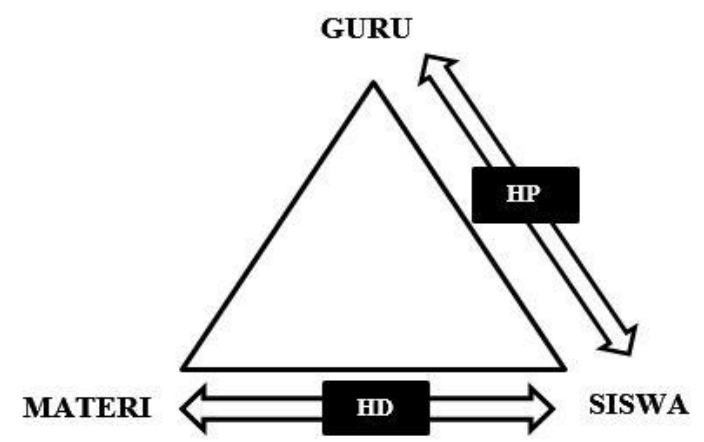

Gambar 1. Segitiga didaktis (HP) dan (HD).

Menurut Suryadi (Nur'ela dkk, 2013) pada saat seorang guru merancang sebuah situasi didakitis atau situasi pembelajaran, juga harus memikirkan prediksi respon siswa yang mungkin terjadi serta antisipasi yang akan diberikan terhadap prediksi-prediksi tersebut. Antisipasi yang diberikan tidak hanya rnenyangkut hubungan siswa dengan materi, akan tetapi juga hubungan guru dan siswa. Sehingga seorang guru dalarn merancang suatu pembelajaran perlu membuat antisipasi yang menyangkut hubungan siswa dengan materi serta hubungan guru dengan siswa atau disebut sebagai Antisipasi Didaktis dan Pedagogis (ADP) yang dibuat berdasarkan kesulitan belajar siswa pada Hukum Pascal. Atas dasar hal tersebut, maka pada segitiga didaktis Kansanen perlu ditambahkan suatu hubungan antisipatif guru-materi yang selanjutnya bisa disebut sebagai Antisipasi Didaktis dan Pedagogis (ADP) sebagaimana diilustrasikan pada gambar segitiga didaktis Kansanen yang dimodifikasi sebagai berikut.

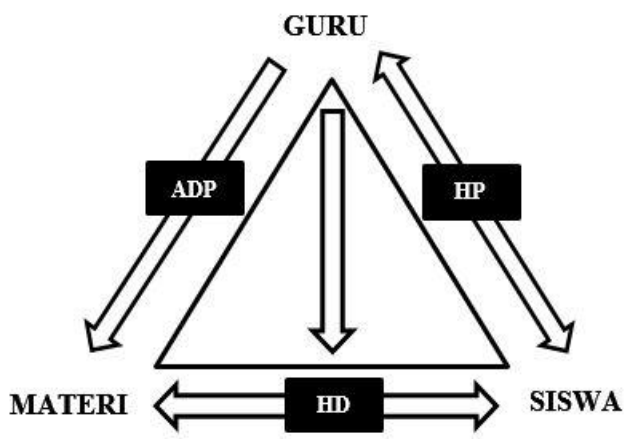

Gambar 2. Segitiga didaktis (HP), (HD), dan (ADP). 
Hasil dari analisis situasi didaktis akan digunakan untuk proses pembuatan rancangan atau desain yang merupakan analisis metapedadidaktik. Analisis metapedadidaktik dilakukan oleh guru dalam implementasi desain didaktis. Metapedadidaktik dapat diartikan sebagai kemampuan guru untuk: (1) memandang komponen-komponen segitiga didaktis yang dimodifikasi yaitu ADP, HD, dan HP sebagai suatu kesatuan yang utuh; (2) mengembangkan tindakan sehingga tercipta situasi didaktis dan pedagogis yang sesuai kebutuhan siswa; (3) mengidentifikasi serta menganalisis respon siswa sebagai akibat tindakan didaktis maupun pedagogis yang dilakukan; (4) melakukan tindakan didaktis dan pedagogis lanjutan berdasarkan hasil analisis respon siswa menuju pencapaian target pembelajaran (Suryadi, 2013). Dalam hal ini guru memiliki peranan penting yang memandang segitiga didaktis sebagai suatu kesatuan yang utuh.

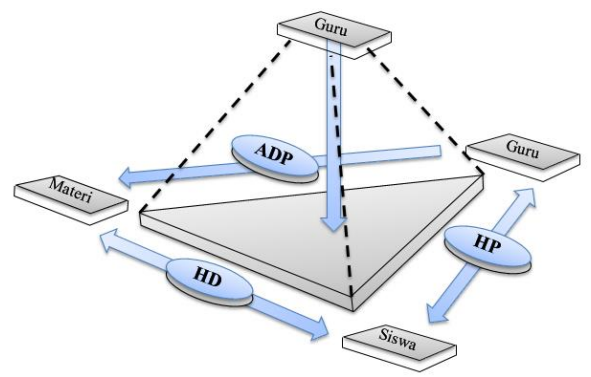

Gambar 3. Metapedadidaktik.

Analisis retrosfektif dilikukan dengan cara membandingkan kemampuan siswa dalam menjawab soal TKR sebelum dan sesudah diterapkannya desain pembelajaran sebagai tindak lanjut dari desain yang telah dibuat. Dari hasil analisis retrosfektif ini akan dihasilkan suatu desain pembelajaran pada Hukum Pascal yang tidak menutup kemungkinan untuk terus dikembangkan.

\section{HASIL DAN PEMBAHASAN}

Siswa yang sudah mempelajari Hukum Pascal diberi soal TKR berupa lima soal esay. Contoh soal nomor satu pada soal TKR adalah sebagai berikut:

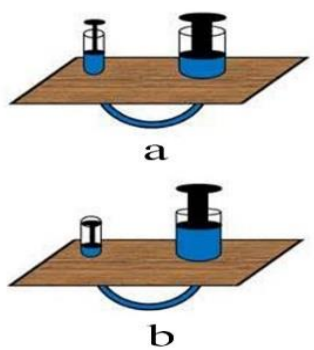

Gambar 4. Soal TKR nomor. 1 (a: sebelum diberi F, b: sesudah diberi F).

Perhatikan gambar di atas! Setelah penampang pipa A diberi gaya sebesar $F$, ternyata secara otomatis penampang pada pipa B menjadi terangkat. Dari kejadian tersebut, tuliskan definisi Hukum Pascal beserta contoh penerapannya dalam kehidupan sehari-hari!

Hasilnya, dari soal TKR awal yang telah diberikan kepada siswa yang sudah mempelajari Hukum Pascal, secara keseluruhan siswa mengalami kesulitan dalam:

1. Definisi Hukum Pascal serta penerapannya dalam kehidupan sehari-hari, diantaranya (a) siswa tidak mampu menuliskan definisi Hukum Pascal dengan benar dan (b) tidak mampu menuliskan contoh alat yang bekerja berdasarkan Hukum Pascal.

2. Perumusan matematis Hukum Pascal serta penjelasan maksud dari perumusan tersebut, dimana (a) siswa tidak mampu menuliskan perumusan matematis dari Hukum Pascal dengan benar, dan (b) siswa tidak mampu menuliskan penjelaskan maksud dari perumusan Hukum Pascal.

3. Aplikasi perumusan Hukum Pascal, diantaranya (a) siswa tidak memahami soal dengan tidak menuliskan diketahui dan ditanyakan dari soal dengan benar, (b) tidak mampu mengkonversikan satuan dengan benar, (c) tidak mengetahui rumus yang akan digunakan, dan (d) tidak menuliskan kesimpulan dari hasil jawabannya dengan benar. 
4. Analisis suatu fenomena menggunakan rumus Hukum Pascal, diantaranya (a) siswa tidak memahami soal dengan tidak menuliskan diketahui dan ditanyakan dari soal dengan benar, (b) tidak mengetahui rumus yang akan digunakan, (c) tidak dapat menganalisis suatu fakta yang diberikan dengan benar, dan (d) tidak menuliskan kesimpulan dari hasil jawabannya dengan benar.

5. Memformulasikan perumusan Hukum Pascal, diantaranya (a) siswa tidak memahami soal dengan tidak menuliskan diketahui dan ditanyakan dari soal dengan benar, (b) tidak mengetahui rumus yang akan digunakan, (c) tidak mengetahui cara mendapatkan gaya, (d) tidak mengetahui cara mendapatkan luas dari jari-jari yang diketahui, (e) tidak mampu memformulasikan rumus dengan benar, dan (f) tidak menuliskan kesimpulan dari hasil jawabannya dengan benar.

Sehingga persentase kesulitan siswa pada soal TKR awal adalah sebagai berikut:

Tabel 1. Kesulitan belajar siswa pada soal TKR awal.

\begin{tabular}{lccc}
\hline $\begin{array}{c}\text { No. } \\
\text { Soal }\end{array}$ & No. Kesulitan & $\begin{array}{c}\text { Jumlah } \\
\text { Siswa }\end{array}$ & Persentase \\
\hline \multirow{2}{*}{1.} & (a) & 5 & $22 \%$ \\
& (b) & 2 & $9 \%$ \\
\hline 2. & $($ a) & 3 & $13 \%$ \\
& (b) & 18 & $78 \%$ \\
\hline & (a) & 4 & $17 \%$ \\
3. & (b) & 17 & $74 \%$ \\
& (c) & 4 & $17 \%$ \\
& (d) & 22 & $96 \%$ \\
\hline & (a) & 9 & $39 \%$ \\
4. & (b) & 7 & $30 \%$ \\
& (c) & 19 & $83 \%$ \\
& (d) & 19 & $83 \%$ \\
\hline & (a) & 8 & $35 \%$ \\
& (b) & 6 & $26 \%$ \\
5. & (c) & 5 & $22 \%$ \\
& (d) & 16 & $70 \%$ \\
& (e) & 15 & $65 \%$ \\
& (f) & 22 & $96 \%$ \\
\hline
\end{tabular}

Selanjutnya dari data kesulitan pada TKR awal, dibuatlah desain pembelajaran untuk meminimalisasi kesulitan tersebut. Pada pelaksanaannya desain diterapkan pada tiga pertemuan di kelas X MIA yang berbeda, yakni kelas X MIA 1, X MIA 2, dan X MIA 3, dan desain didaktis tersebut selalu mengalami perbaikan di setiap pertemuannya agar desain yang dibuat menjadi lebih baik lagi.

Implementasi disain pertama yaitu di kelas $X$ MIA 3 dengan jumlah siswa sebanyak 30 orang. Dari pertemuan pertama, disain mengalami perbaikan untuk pertemuan selanjutnya, dimana disain kedua yang merupakan hasil perbaikan dari pertemuan pertama diimplementasi di kelas $\mathrm{X}$ MIA 1 dengan jumlah siswa sebanyak 26 orang. Terakhir, disain kedua mengalami perbaikan kembali untuk pertemuan ketiga di kelas X MIA 2 dengan jumlah siswa sebanyak 34 orang, sehingga dengan adanya perbaikan di setiap pertemuannya diharapkan disain yang dibuat benar-benar mampu meminimalisasi kesulitan belajar siswa pada Hukum Pascal.

Sebagai contoh disain untuk meminimalisasi kesulitan belajar siswa pada definisi Hukum Pascal serta penerapannya dalam kehidupan sehari-hari beserta hasil perbaikan di setiap pertemuannya adalah sebagai berikut:

Tabel 2. Disain didaktis pada soal nomor 1 .

\begin{tabular}{lll}
\hline Pertemuan 1 & Pertemuan 2 & \multicolumn{2}{c}{ Pertemuan 3 } \\
\hline - Guru & $\bullet$ Guru meminta & $\bullet$ Guru meminta \\
melakukan & siswa untuk & siswa untuk \\
demonstrasi & menuliskan & menuliskan \\
menggunaka & nama dari alat & nama dari alat \\
n alat hidrolik & yang akan & yang akan \\
sederhana. & didemonstrasi & didemonstrasi \\
- Guru & kan. & kan. \\
meminta & $\bullet$ Guru & $\bullet$ Guru \\
siswa & menanyakan & menanyakan \\
mengamati & apa & apa \\
apa yang & perbedaannya & perbedaannya \\
terjadi jika & alat hidrolik & alat hidrolik \\
salah satu & sederhana & sederhana \\
penampang & dengan pipa U. & dengan pipa U. \\
hidrolik & $\bullet$ Guru & $\bullet$ Guru \\
diberi gaya. & melakukan & melakukan \\
& demonstrasi & demonstrasi \\
\hline
\end{tabular}




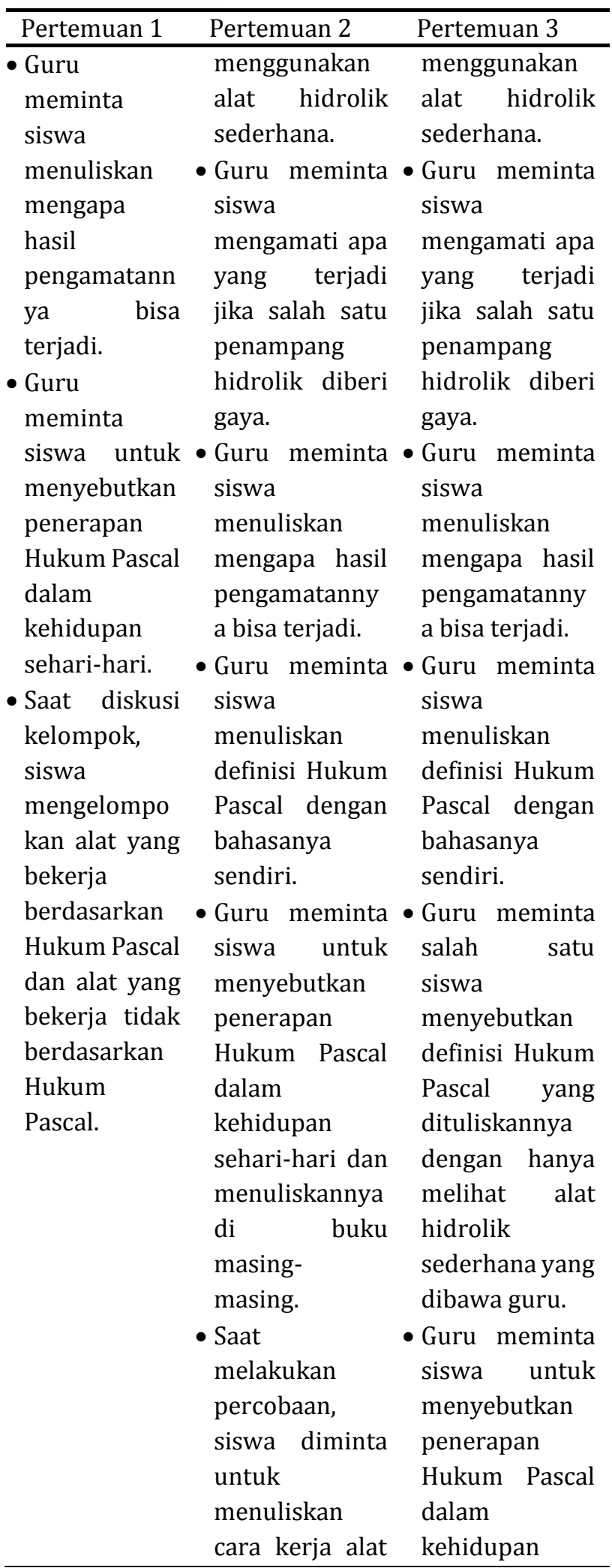

\begin{tabular}{lll}
\hline Pertemuan 1 & Pertemuan 2 & Pertemuan 3 \\
\hline & hidrolik & sehari-hari dan \\
& sederhana. & menuliskannya \\
& & di buku \\
& masing- \\
& masing. \\
& - Saat \\
& melakukan \\
& percobaan, \\
& siswa diminta \\
& untuk \\
& menuliskan \\
& cara kerja alat \\
& hidrolik \\
& sederhana. \\
\hline
\end{tabular}

Untuk melihat keberhasilan desain yang telah dibuat, maka soal TKR diberikan kepada siswa di akhir setiap pertemuan, yaitu pertemuan pertama dengan Disain 1 (D1), pertemuan kedua dengan Disain 2 (D2), dan pertemuan ketiga dengan Disain 3 (D3). Hasilnya terlihat penurunan persentase setelah diterapkannya desain yang telah mengalami perbaikan, sepertai data yang terlihat pada tabel di bawah ini.

Tabel 3. Perbandingan persentase kesulitan belajar siswa.

\begin{tabular}{lccccc}
\hline $\begin{array}{c}\text { No. } \\
\text { Soal }\end{array}$ & $\begin{array}{c}\text { No. } \\
\text { Kesulitan }\end{array}$ & $\begin{array}{c}\text { TKR } \\
\text { Awal }\end{array}$ & D 1 & D 2 & D 3 \\
\hline \multirow{2}{*}{1.} & (a) & $22 \%$ & $10 \%$ & $8 \%$ & $3 \%$ \\
& (b) & $9 \%$ & $3 \%$ & $0 \%$ & $0 \%$ \\
\hline \multirow{2}{*}{2.} & (a) & $13 \%$ & $10 \%$ & $0 \%$ & $0 \%$ \\
& (b) & $78 \%$ & $83 \%$ & $46 \%$ & $24 \%$ \\
\hline & (a) & $17 \%$ & $10 \%$ & $8 \%$ & $3 \%$ \\
3. & (b) & $74 \%$ & $27 \%$ & $23 \%$ & $18 \%$ \\
& (c) & $17 \%$ & $13 \%$ & $4 \%$ & $0 \%$ \\
& (d) & $96 \%$ & $73 \%$ & $54 \%$ & $47 \%$ \\
\hline & (a) & $39 \%$ & $10 \%$ & $4 \%$ & $3 \%$ \\
4. & (b) & $30 \%$ & $17 \%$ & $8 \%$ & $0 \%$ \\
& (c) & $83 \%$ & $67 \%$ & $19 \%$ & $15 \%$ \\
& (d) & $83 \%$ & $87 \%$ & $65 \%$ & $26 \%$ \\
\hline & (a) & $35 \%$ & $23 \%$ & $19 \%$ & $9 \%$ \\
& (b) & $26 \%$ & $23 \%$ & $12 \%$ & $9 \%$ \\
5. & (c) & $22 \%$ & $20 \%$ & $12 \%$ & $9 \%$ \\
& (d) & $70 \%$ & $57 \%$ & $12 \%$ & $12 \%$ \\
& (e) & $65 \%$ & $63 \%$ & $15 \%$ & $9 \%$ \\
& (f) & $96 \%$ & $97 \%$ & $62 \%$ & $47 \%$ \\
\hline
\end{tabular}


JoTaLP: Journal of Teaching and Learning Physics 1, 2 (2016): 1-9

Website: http://journal.uinsgd.ac.id/index.php/jtlp/index ISSN 2580-3107 (online) ISSN 2528-5505 (print)

Adapun kenaikan persentase pada pertemuan pertama, dimana kesulitan belajar siswa pada soal nomor kedua mengenai kesulitan pada poin (b) dalam menjelaskan maksud dari perumusan Hukum Pascal yang mengalami kenaikan sebesar 5\%, dari 78\% menjadi 83\%. Pada soal nomor empat mengenai kesulitan pada poin (d) dalam menuliskan kesimpulan dari hasil jawabannya dengan benar juga mengalami kenaikan sebesar 4\%, dari $83 \%$ menjadi $87 \%$. Dan terakhir pada soal nomor lima, juga mengenai kesulitan pada poin (f) dalam menuliskan kesimpulan dari hasil jawabannya dengan benar mengalami kenaikan sebesar $1 \%$, dari 96\% menjadi 97\%. Hal ini terjadi karena pada pertemuan pertama merupakan implementasi desain yang pertama bagi peneliti sehingga desain yang dibuat masih hanya didasarkan pada hasil analisis TKR awal, dan juga peneliti dirasa belum maksimal dalam mengimplementasikan desain tersebut. Namun, setelah mengalami perbaikan desain, dan memiliki gambaran tentang keadaan kelas yang sebenarnya, maka pada pertemuan selanjutnya, kesulitan tersebut dapat diminimalisasi kembali.

Untuk lembar observasi, dari tiga pertemuan yang telah dilaksanakan dalam implementasi desain didaktis, nilai keterlaksanaan kegiatan guru dan siswa dapat dilihat pada lembar observasi yang telah diisi oleh tiga observer di setiap pertemuannya. Hasilnya akan diolah sehingga dapat terlihat sejauh mana keterlaksanaan kegiatan guru dan siswa dalam proses pembelajaran tersebut dapat dilaksanakan. Untuk keterlaksanaan kegiatan guru selama tiga pertemuan ditunjukan oleh tabel sebagai berikut.

Tabel 4. Keterlaksanaan kegiatan guru.

\begin{tabular}{cccc}
\hline & \multicolumn{3}{c}{ Kegiatan Guru } \\
\cline { 2 - 4 } Pertemuan & $\begin{array}{c}\text { Skor } \\
\text { rata- } \\
\text { rata }\end{array}$ & $\%$ & Interpretasi \\
\hline 1. & 206 & $83 \%$ & Baik \\
\hline 2. & 253 & $87 \%$ & Baik \\
\hline 3. & 279 & $92 \%$ & Sangat Baik \\
\hline
\end{tabular}

\begin{tabular}{cccc}
\hline \multirow{2}{*}{ Pertemuan } & \multicolumn{3}{c}{ Kegiatan Guru } \\
\cline { 2 - 4 } & $\begin{array}{c}\text { Skor } \\
\text { rata- } \\
\text { rata }\end{array}$ & $\%$ & Interpretasi \\
\hline Jumlah & $\begin{array}{c}\text { Rata- } \\
\text { rata }\end{array}$ & $87 \%$ & Baik \\
\hline
\end{tabular}

Sedangkan untuk keterlaksanaan kegiatan siswa selama tiga pertemuan adalah sebagai berikut.

Tabel 5. Keterlaksanaan kegiatan siswa.

\begin{tabular}{cccc}
\hline \multirow{3}{*}{ Pertemuan } & \multicolumn{3}{c}{ Kegiatan Siswa } \\
\cline { 2 - 4 } & $\begin{array}{c}\text { Skor } \\
\text { rata- } \\
\text { rata }\end{array}$ & $\%$ & Interpretasi \\
\hline 1. & 201 & $80 \%$ & Baik \\
\hline 2. & 248 & $86 \%$ & Baik \\
\hline 3. & 275 & $90 \%$ & Sangat Baik \\
\hline Jumlah & $\begin{array}{r}\text { Rata- } \\
\text { rata }\end{array}$ & $85 \%$ & Baik \\
\hline
\end{tabular}

Dari data mengenai keterlaksanaan kegiatan guru dan siswa terlihat bahwa pelaksanaan proses pembelajaran mengalami peningkatan di setiap pertemuannya seiring dengan bertambahnya gambaran dan wawasan peneliti tentang kondisi kelas yang sebenarnya serta cara mengatasinya.

\section{KESIMPULAN}

Berdasarkan hasil penelitian Didactical Design Research (DDR) Pada Hukum Pascal, dapat disimpulkan bahwa kesulitan belajar siswa pada Hukum Pascal sebagai berikut: (1) Kesulitan belajar siswa dalam menuliskan definisi dan penerapan dalam kehidupan sehari-hari. Siswa tidak mampu menuliskan definisi Hukum Pascal dengan benar. Siswa tidak mampu menuliskan contoh alat yang bekerja berdasarkan Hukum Pascal. (2) Kesulitan belajar siswa dalam menuliskan dan menjelaskan maksud dari perumusan Hukum Pascal. Siswa tidak mampu menuliskan perumusan matematis dari Hukum Pascal dengan benar. Siswa tidak mampu menuliskan penjelaskan maksud dari perumusan 
Hukum Pascal. (3) Kesulitan belajar siswa dalam mengaplikasikan Hukum Pascal. Siswa tidak memahami soal dengan tidak menuliskan diketahui dan ditanyakan dari soal dengan benar. Siswa tidak mampu mengkonversikan satuan dengan benar. Siswa tidak mengetahui rumus yang akan digunakan. Siswa tidak menuliskan kesimpulan dari hasil jawabannya dengan benar. (4) Kesulitan belajar siswa dalam menganalisis fakta menggunakan Hukum Pascal. Siswa tidak memahami soal dengan tidak menuliskan diketahui dan ditanyakan dari soal dengan benar. Siswa tidak mengetahui rumus yang akan digunakan. Siswa tidak dapat menganalisis suatu fakta yang diberikan dengan benar. Siswa tidak menuliskan kesimpulan dari hasil jawabannya dengan benar. (5) Kesulitan belajar siswa dalam memformulasikan perumusan Hukum Pascal. Siswa tidak memahami soal dengan tidak menuliskan diketahui dan ditanyakan dari soal dengan benar. Siswa tidak mengetahui rumus yang akan digunakan. Siswa tidak mengetahui cara mendapatkan gaya. Siswa tidak mengetahui cara mendapatkan luas dari jari-jari yang diketahui. Siswa tidak mampu memformulasikan rumus dengan benar. Siswa tidak menuliskan kesimpulan dari hasil jawabannya dengan benar.

Selanjutnya rekomendasi desain didaktis pada Hukum Pascal secara garis besar adalah sebagai berikut: (1) Desain didaktis pada konsep Hukum Pascal yakni dengan demonstrasi alat hidrolik sederhana. (2) Desain didaktis pada perumusan Hukum Pascal yakni dengan menampilkan video tentang pengaruh luas penampang terhadap besar tekanan. (3) Desain didaktis pada aplikasi Hukum Pascal dengan latihan soal. (4) Desain didaktis pada analisis Hukum Pascal dengan latihan soal. (5) Desain didaktis pada formulasi Hukum Pascal dengan diskusi kelompok.

Untuk keterlaksanaan kegiatan guru dan siswa yang terdapat pada lembar observasi, menunjukan gambaran keterlaksanaan implementasi desain yang telah dibuat. Hasilnya dari tiga pertemuan yang telah dilakukan, nilai rata-rata untuk keterlaksanaan kegiatan guru adalah sebesar $87 \%$ dengan interpretasi baik, sedangkan untuk keterlaksanaan kegiatan siswa sebesar 85\% dengan interpretasi baik pula.

Adapun saran yang dianjurkan dari penelitian yang telah dilakukan: (1) Pemilihan materi diusahakan satu bab. Tujuannya agar desain yang dibuat dapat dikembang lagi. (2) Desain yang dibuat diimplementasikan di satu kelas dalam 3 pertemuan. Tujuannya untuk memudahkan dalam melihat keberhasilan desain dalam meminimalisasi kesulitan belajar siswa karena diimplementasikan pada siswa yang sama. (3) Menggali lebih dalam lagi tentang cara guru mengajar sebelum penelitian dilakukan. Hal ini bertujuan agar peneliti memiliki gambaran lebih jelas tentang situasi pembelajaran dalam rangka pembuatan desain didaktis

\section{UCAPAN TERIMAKASIH}

Ucapan terimakasih ditunjukan kepada semua pihak yang telah membantu peneliti selama proses penelitian berlangsung, kepada pihak sekolah MAN Cililin Kabupaten Bandung Barat yang telah memberi izin tempat dalam penelitian ini, sehingga dapat berjalan dengan lancar. Dengan demikian mudah-mudahan penelitian ini bermanfaat dan menjadi amal kebaikan bagi kita semua, amin.

\section{DAFTAR PUSTAKA}

Ismail, M. Ilyas. 2010. Kinerja Dan Kompetensi Guru. Tersedia online di: http://scholar.google.co.id/scholar?start= $60 \& \mathrm{q}=$ teori+mengajar+seorang + guru $\& \mathrm{hl}=\mathrm{i}$ $\underline{\mathrm{d} \& a s} \mathrm{sdt}=0,5$. Lentera pendidikan, Vol. 13 No.1. diunduh pada tanggal 25 November pukul. 07.45 WIB.

Nur'ela, dkk. 2013. Desain Didaktis Konsep Garis Singgung Lingkaran Pada Pembelajaran Matematika Sekolah Menengah Pertama (SMP). Tersedia online di: http://journal.fpmipa.upi.edu/index.php/i opmk/article/view/31/26. Jurnal online pendidikan matematika kontemporer. Vol 
1, no 1. Diunduh pada tanggal 24 November 2015 pukul 07.17 WIB.

Purwanto, Ngalim M. 2008. Prinsip-prinsip dan Teknik Evaluasi Pengajaran. Bandung: PT. Remaja Rosdakarya.

Rusilowati, Ani. 2006. Profil Kesulitan Belajar Fisika Pokok Bahasan Kelistrikan Siswa Sma Di Kota Semarang. Tersedia online di: https://scholar.google.co.id/scholar?hl=id \&q=jurnal+kesulitan+belajar\&btnG Jurnal Pend. Fisika Indonesia Vol. 4, No. 2. Diunduh pada tanggal 7 November 2015 pukul 20.00 WIB.

Rusilowati, Ani. 2007. Diagnosis Kesulitan Belajar Fisika Siswa SD, SMP, Dan SMA Dengan Teknik General Diagnostic Dan Analytic Diagnostic. Teredia online di: http://eprints.uny.ac.id/12104/. Diunduh pada tanggal 30 Oktober 2015 pukul 21.00 WIB.

Soenarto, Sunaryo. 2011. Pengaruh Strategi Pembelajaran Dan Cara Berpikir Terhadap Hasil Belajar Fisika. Tersedia online di: http://scholar.google.co.id/scholar?start= $10 \& \mathrm{q}=$ cara + mengajar+fisika+yang+baik\&h $\underline{\mathrm{l}=\mathrm{id} \& \text { as } \mathrm{sdt}=0,5}$. Jurnal Prosidang Seminar Nasional Penelitian, Pendidikan dan Penerapan MIPA. Diunduh pada tanggal 25 November 2015 pukul 06.37 WIB.

Stacy A. Brown. 2008. Exploring Epistemological Obstacles to the Development of Mathematics Induction. Conference for Research on Undergraduate Mathematics Education. San Diego, CA.

Sukmadinata, Nana Syaodih. 2012. Metode Penelitian Pendidikan. Bandung: PT Remaja Rosdakarya

Suryadi, Didi. 2013. Didactical Design Research (DDR) Dalam Pengembangan Pembelajaran Matematika. Tersedia di: http://scholar.google.co.id/scholar?hl=id\& as $\mathrm{sdt}=0,5 \& \mathrm{q}=$ didactical+design+research + dalam+pengembangan+pembelajaran $+m$ atematika. Diunduh pada tanggal 30 Oktober 2015 pukul 20.24 WIB. 